\title{
Tips for Readers, Reviewers, and Authors Advancing Health and Primary Health Care
}

\author{
Kurt C. Stange, $M D, P b D$, Editor and Robin S. Gotler, MA, Reflections Editor \\ Ann Fam Med 2014;299-301. doi: 10.1370/afm.1675.
}

A nnals authors, reviewers, and readers are part of a learning community that is working to advance health and improve primary health care. Below we share tips to help each group enhance their role in this community. We invite you to refine and expand these tips by joining the discussion at http://www.annfammed org/content/12/4/299, or on Twitter@AnnFamMed.

\section{TIPS FOR READERS}

The Annals offers a variety of insights into articles.

- For individual articles, read In Brief article summaries at http://annfammed.org/site/misc/InBrief.xhtml

- Groups of articles are collected by type and by unique topics and themes. These unique groupings are specific to primary care and include topics that are often missed in usual searches. Visit http://www. annfammed.org/cgi/collection

- Reflections articles, covering a wide variety of personal stories and timely topics, are collected in a recently-published book, The Wonder and the Mystery. More information at http://annfammed.org/site/misc/ book.xhtml

- Share your insights. Join authors, reviewers, and other readers in an online dialogue around published Annals articles (Table 1)

All content is available online, free of charge, without subscription. To keep up with your topics of interest, sign up for email alerts at http://annfammed.org/cgi/alerts and RSS feeds at http://annfammed.org/rss/, and register to receive the table of contents with links to the entire content of Annals at http://lyris.aafp.org/subscribe/annals/.

\section{TIPS FOR REVIEWERS}

The goal of peer review is to help authors improve their work and help editors make decisions.
Reviewers bring diverse experience and expertise to the journal, and the experience gained in reviewing helps reviewers develop their own writing and critical reading skills. We select reviewers with differing but complementary experience and expertise, so reviewers can feel free to focus their comments on what they know best. To sign up as a reviewer, complete the registration form at http://annfammed.org/site/misc/ reviewerinfo.xhtml.

Authors tell us that the most helpful reviews are 1 to 2 pages long, and:

- Include general comments that provide an overall reaction and broad suggestions for improving the quality of the work or clarity of the presentation

- Include specific comments (often citing relevant pages and paragraphs) about particular parts of the paper that raise questions or point out areas that might need work

- Do not address grammatical or punctuation errors (This is handled through a separate copy editing process)

We encourage reviewers to provide confidential comments to the editors as well. These may include additional observations about what a manuscript contributes beyond what is already known and the importance of the work compared to other literature

\section{Table 1. Discussion: Key to a Learning Community}

Readers, authors, and reviewers bring research to life through online discussion.

Readers

Post a comment at http://annfammed.org/letters, ranging from a quick reaction, a reflection on your relevant experience, or a more in-depth analysis. Comments become part of the formal record for each article and can be cited on your CV.

Tweet or blog about Annals articles and discussions. Follow the Annals@AnnFamMed.

Use the Annals tip sheet, with media-friendly summaries of each article, to develop blogs and tweets. To receive the tip sheet, contact AnnFamMed@case.edu.

\section{Authors}

Create a dialogue by responding to reader comments.

Encourage colleagues, students, policymakers, and others to take part in the discussion. Reviewers

Your in-depth knowledge of the article and topic can enhance the discussion. Post a comment or share your thoughts in social media. 
and/or areas of research. Your judgment about the following helps editors in their decision making:

- The degree to which the study is new, useful, valid, and relevant

- Whether the length of the manuscript is commensurate with the value of the information

- Whether the paper can be revised into a high quality manuscript

Detailed information on reviewing is available on the Annals website at http://annfammed.org/site/misc/ pdfsanddocs/ReviewerInstructions.pdf.

\section{TIPS FOR AUTHORS}

We encourage authors to write concise, focused articles that contribute new information to the field.

\section{Communicating Effectively With Words, Pictures, and Tables}

The length of articles should be based on the degree to which the paper makes a novel contribution to the field and the nature of the research design and method. (See the revised Instructions for Authors at http://annfammed.org/site/misc/pdfsanddocs/ InstructionsForAuthors.pdf). Please use the minimum number of words, figures, and tables needed to effectively and concisely convey information.

- Brief manuscripts provide an opportunity to communicate a single, crisp, powerful idea or new ideas evaluated with small samples or other limitations

- Longer articles convey fully developed, rigorous exposition of a topic

- Many topics are most effectively communicated in article lengths between brief manuscripts and longer articles

Qualitative research, at times, may convey a topic with more words and fewer tables/figures. However, readers are often interested in articles that synthesize themes and quotations to convey their essence, with higher-order interpretive analyses that draw out larger meaning and theory, often including a diagram or table that draws concepts together.

In both qualitative and quantitative papers, tables and figures should convey meaning on their own, separate from the paper. Avoid repeating in words what can be discerned from tables and figures. Additional details that are likely to be relevant for a minority of readers can be included in an appendix.

\section{Conveying Relevant Contextual Factors}

Most standards for rigor in research focus on internal validity, which relates primarily to the legitimacy of inferences about the cause-effect or causal relationships among factors assessed within the bounds of a study. Internal validity is important, and there are many guidelines on how to realize it.

External validity, the degree to which findings from one study can be generalized or transported to another setting or situation, is also important and is a key question for readers. Guidelines for research rigor are largely silent on external validity.

We encourage authors to briefly report contextual factors that affect what happened and why in their research. Reporting contextual factors can help readers assess the external validity of research and make informed judgments about how to transport and reinvent the findings in their own settings.

Reporting contextual factors that affect external validity is not easily amenable to a checklist approach. However, by involving multiple stakeholders in paying attention to contextual factors at different points in the research, relevant context can be identified and reported across multiple levels, from the policy environment to the health care system, practice, participant, and research team. ${ }^{1}$

- Contextual factors relevant to how the study was done or how the methods changed during the course of the study often are most helpfully reported in the methods

- In most papers, it is highly desirable to include in the discussion section a paragraph on contextual factors relevant to interpreting or using the findings in other settings

- For examples and a "Context Matters" worksheet, see Table 2

\section{Engaging Target Audiences}

We ask authors to explicitly consider the diverse audiences for whom their work is relevant and to write in ways that are accessible to those audiences. When we accept a manuscript, we will ask you to provide names and email addresses of people interested in your work, and we will invite them to participate in the Annals' online discussion.

\section{Table 2. Reporting Context}

Report multilevel contextual factors affecting the external validity and transportability of research, policy, or practice.

\section{Examples}

Fourteen research teams assessed and reported contextual factors as appendixes to their research articles. ${ }^{2}$ A summary of their observations is available. ${ }^{3}$

\section{Worksheet}

A "Context Matters" worksheet has been developed and can serve as a starting point in assessing and briefly reporting context as an additional paragraph in the Methods and/or Discussion sections of a manuscript. It is available at http://annfammed.org/content/11/ Suppl_1/S115/F2. 


\section{A LEARNING COMMUNITY OF READERS, REVIEWERS, AND AUTHORS}

When readers are engaged in applying and reflecting, when reviewers help to assure the publication of high quality research and reflections, and when authors consider their audiences and effectively convey both internally valid work and relevant contextual factors, a learning forum is created that is more than the sum of its parts. We are grateful for the chance to participate in this learning community, and appreciate the commitment of the Annals' sponsoring organizations to create space for a transdisciplinary, international, interactive forum for advancing new knowledge to understand and improve health and primary health care.
To read or post commentaries in response to this article, see it online at http://www.annfammed.org/content/12/4/299.

\section{References}

1. Agency for Healthcare Research and Quality (AHRQ). Patientcentered Medical Home Resource Center. Contextual factors: the importance of considering and reporting on context in the patientcentered medical home. http://pcmh.ahrq.gov/page/contextualfactors-importance-considering-and-reporting-context-researchpatient-centered.

2. Transforming Primary Care. [supplement]. Ann Fam Med. 2013(Suppl 1):S1-S123.

3. Tomoaia-Cotisel A, Scammon DL, Waitzman NJ, et al. Context matters: the experience of 14 research teams in systematically reporting contextual factors important for practice change. Ann Fam Med. 2013:11(Suppl 1):S115-S123.

\section{CORRECTIONS}

Ann Fam Med 2014;301. doi: 10.1370/afm.1674

Elwyn G, Dehlendorf C, Epstein RM, et al. Shared decision making and motivational interviewing: achieving patient-centered care across the spectrum of health care problems. Ann Fam Med. 2014;12(3):270-275.

In the print version of the May/June (v. 12, no. 3) table of contents, the article by Elwyn et al was listed as Original Research when it actually was a Reflections article. It is correct in the online version of Annals. The print version therefore departs from the online version.

Sox HC. Do clinical guidelines still make sense? Yes. Ann Fam Med. 2014;12(3):200-201.

Upshur RE. Do clinical guidelines still make sense? No. Ann Fam Med. 2014;12(3):202-203.

In the print version of the May/June (v. 12, no. 3) table of contents, the articles by Sox and Upshur were incorrectly listed in the Editorials section and should have been listed as Point/Counterpoint articles. It is correct in the online version of the Annals. The print version therefore departs from the online version.

Additionally, in the print table of contents of the May/June (v. 12, no. 3) issue the author's surname Sox was spelled incorrectly as Cox. It is correct in the Annals online table of contents. The print version therefore departs from the online version. 